\title{
Immunoglobulin-containing cells in jejunal mucosa of children with protein-energy malnutrition and gastroenteritis
}

\author{
F GREEN AND B HEYWORTH
}

Department of Pathology, University of Manchester, and Medical Research Council, Fajara, Gambia

SUMMARY Jejunal biopsies from 20 well nourished children (average age 12.8 months) with gastroenteritis, and 20 children (average age 20 months) with protein-energy malnutrition were examined by immunofluorescent technique for immunoglobulins $A, G, M, E$, and $D$, and for epithelial glycoprotein secretory component. Compared with previous studies on normal infants, the children with gastroenteritis showed a moderate increase in IgA-containing cells, a large increase in IgMcontaining cells, and no change in IgG-containing cells. These findings are similar to previously recorded findings on adults with gastroenteritis. In contrast there was a pronounced and highly significant decrease in IgA-containing cells in the jejunal mucosa of the children with protein-energy malnutrition. No significant differences were noted between the populations of IgG-, IgM-, IgE-, and IgD-containing cells in the two groups. It is suggested that this selective deficiency in mucosal IgA results from a delay in maturation of the secretory IgA system, and the mechanisms of such a deficiency are discussed.

Infections, particularly of the respiratory and gastrointestinal tracts, are common in malnourished children. ${ }^{1}$ Malnutrition can impair resistance to infection in many ways, particularly by producing a deficiency in host defences. Various abnormalities of the immune mechanism in children with proteinenergy malnutrition (PEM) have been shown-such as lymphopenia, ${ }^{2}$ complement defects, ${ }^{3}$ depressed cell-mediated immunity, ${ }^{4-7}$ and reduced phagocytic activity of leucocytes. ${ }^{8}$ However, the levels of serum immunoglobulins have been reported to be normal. ${ }^{-11}$ Several recent reports have described abnormalities of the secretory IgA (S IgA) response in PEM, such as a reduced nasopharyngeal secretory antibody response to live attenuated measles and polio virus vaccines, ${ }^{12}$ a selective deficiency of $\mathrm{S}$ IgA in the nasal secretions, ${ }^{13}$ and a decreased concentration of S IgA in duodenal fluid, saliva, nasal secretions, and tears. ${ }^{11}$ No studies have quantified the immunoglobulin-containing cells in the jejunal mucosa in PEM. In view of the importance of the

National Institute of Occupational Safety and Health ALOSH, Morgantown, West Virginia, USA

F GREEN, chief of pathology

Mater Children's Hospital, South Brisbane, Queensland, Australia

B HEYWORTH, medical director secretory antibody system in mucosal immunity, this aspect was studied in a group of children with PEM and the results were compared with a group of well nourished children with acute gastroenteritis.

\section{Materials and methods}

Jejunal biopsies were taken by the double-lumen technique described previously. ${ }^{14}$ The biopsies were from African children in the MRC Research Unit, Fajara, Gambia, with the consent of the parents. The patients were divided into two groups; the first comprised 25 children suffering from marasmus, kwashiorkor, or marasmic-kwashiorkor. Their ages ranged from 9 to 34 months, with a mean age of 20 months; the second group comprised 20 well nourished children with acute gastroenteritis. Their ages ranged from 4 to 33 months, with a mean age of 12.8 months. Clinical details of the children with PEM have been given. ${ }^{14}$

The jejunal biopsies were quickly frozen in liquid nitrogen, mounted on cryostat chucks, and a series of $5 \mu \mathrm{m}$ sections obtained. The biopsy was then removed from the chuck, immersed in formalin solution, and processed for routine light microscopical examination. The cryostat sections were fixed in acetone for $\mathbf{3}$ minutes and air dried. 
Sections were stained by both direct and indirect immunofluorescent procedures using commercially available antisera to the heavy chains of human IgA, IgG, IgM, IgD, and IgE, and to human secretory component. Sources of reagents and details of the method and controls have been reported. ${ }^{15}$

Stained sections were viewed in a Leitz Ortholux microscope equipped for fluorescence microscopy. The numbers of fluorescent cells in the mucosa were quantified using an eye piece grid at $\times 100$ magnification. Cells from at least 10 high power fields were counted and results were expressed as numbers of fluorescent cells per $\mathrm{mm}^{2}$ of mucosa.

\section{Results}

Light microscopical examination. Haemotoxylin and eosin-stained sections of 18 of the 25 biopsies from children with PEM were considered of sufficiently good quality to be interpretable; 10 of these were considered normal for African children on doubleblind examination. The remaining 8 showed varying degrees of villous atrophy. In the group with gastroenteritis, 10 of the 17 good quality sections were assessed as normal, and 7 showed partial villous atrophy.

\section{Fluorescent microscopical examination.}

\section{Acute gastroenteritis}

All 20 biopsies were of sufficiently good quality for fluorescent microscopical examination. Fluorescent cells were detected in the lamina propria of the mucosa in all cases and were particularly numerous in the region of the crypts. Restaining sections with haematoxylin and eosin showed that these cells had the morphological characteristics of either plasma cells or large lymphoblasts. In 15 specimens IgAcontaining cells predominated in the lamina propria; in the remaining 5 specimens cells staining for IgM equalled or exceeded those staining for IgA. IgGcontaining cells were fewer than IgA- or IgMcontaining cells. Very few IgE- or IgD-containing cells were seen and in many cases these were absent. In view of their limited number these cells were not quantified. The means and SDs for the populations of immunocytes staining for $\operatorname{IgA}, \operatorname{IgM}$, and $\operatorname{IgG}$ are shown in the Table. The ratio of IgA:IgM:IgG was approximately 10:7:1. IgA was detected in the apical cytoplasm and along the cell borders of the columnar epithelial cells of the crypts. Similarly distributed intraepithelial IgM was seen in most cases. Intraepithelial IgG was not seen. Secretory component was seen in the columnar epithelial cells of both crypts and villi, and was uniformly distributed throughout the cytoplasm.
Table Immunoglobulin-containing cells in the jejunal mucosa

\begin{tabular}{|c|c|c|c|}
\hline Group & $\begin{array}{l}\text { IgA-containing } \\
\text { cells/mm } \mathbf{m}^{2} \\
(\text { mean } \pm S D)\end{array}$ & $\begin{array}{l}\text { IgM-containing } \\
\text { cells } / m^{2} \\
(\text { mean } \pm S D)\end{array}$ & $\begin{array}{l}\text { IgG-containing } \\
\text { cells } / m^{2} \\
(\text { mean } \pm S D)\end{array}$ \\
\hline $\begin{array}{l}\text { Gastroenteritis } \\
(n=20)\end{array}$ & $705 \cdot 9 \pm 166 \cdot 3$ & $465 \cdot 9 \pm 211 \cdot 2$ & $73 \cdot 3 \pm 78 \cdot 9$ \\
\hline \multirow{2}{*}{$\begin{array}{l}\text { Protein-energy } \\
\text { malnutrition } \\
(n=20)\end{array}$} & $454 \cdot 6 \pm 156 \cdot 8$ & $393 \cdot 7 \pm 142 \cdot 5$ & $40 \cdot 8 \pm 35 \cdot 8$ \\
\hline & ${ }^{*} \mathrm{P}<0.001$ & NS & NS \\
\hline
\end{tabular}

*Student's $t$ test assuming a normal distribution within the groups.

Protein-energy malnutrition. Only 20 of the 25 specimens were of suitable quality for immunofluorescent studies. Four samples were rejected because there was insufficient tissue and one because it consisted of stomach. Fewer cells staining for IgA, $\mathrm{IgM}$, and IgG were found in the mucosa of children with PEM than in children with gastroenteritis (Table). The differences between the number of IgMand IgG-containing cells were not significant. There was however, a pronounced and significant reduction $(\mathrm{P}<0.001)$ in the number of IgA-containing cells. The ratio of IgA:IgM:IgG was approximately 7:6:0.5. IgE- and IgD-containing cells were encountered very rarely and were not quantified. Intraepithelial IgA, IgM, and secretory component showed a distribution similar to that seen in patients with gastroenteritis.

\section{Discussion}

There have been no previous studies of immunoglobulin-containing cells in the jejunum of children with PEM. A control population was not used because it was considered unethical to carry out biopsies on normal infants. Therefore, well nourished children of the same cultural and ethnic background with gastroenteritis served as controls. This limitation to the study design made the interpretation of the data somewhat difficult. Fortunately we were able to compare our data with the results reported by Savilahti. ${ }^{16}$

On a population of 13 normal white infants aged between 3 months and 2 years, Savilahti ${ }^{16}$ showed that the means for IgA-, IgM-, and IgG-containing cells were $580( \pm 193), 205( \pm 144)$, and $68( \pm 47)$ cells per $\mathrm{mm}^{2}$ of mucosa respectively. In our study the means of IgA-, IgM-, and IgG-containing cells in the gastroenteritis patients were $705 \cdot 9( \pm 166 \cdot 3)$, $465.9( \pm 211 \cdot 2)$, and $73 \cdot 3( \pm 78 \cdot 9)$ cells per $\mathrm{mm}^{2}$ respectively. Thus in gastroenteritis, there appears to be a moderate increase in IgA-containing cells, a large increase in IgM-containing cells, and no change in IgG-containing cells. Similar findings were 
reported by Søltoft and Søeberg ${ }^{17}$ in a serial study of adult patients with gastroenteritis in which increases in IgA- and IgM-containing cells were shown but not in IgG-containing cells.

The PEM group, on the other hand, show a reduction in numbers of IgA- and IgG-containing cells, and an increase in IgM-containing cells when compared with Savilahti's normal infants. Thus, in PEM there appears to be an absolute decrease in the number of $\operatorname{IgA}$-containing cells in the jejunal mucosa. However, these conclusions must be interpreted with caution as the populations being compared were racially and geographically distinct.

If the numbers of immunocytes in the jejunal mucosa in PEM are compared with those seen in gastroenteritis there is a highly significant $(P<0.001)$ decrease in the population of IgA-containing cells. Significant differences were not found in the populations of either IgM- or IgG-containing cells. This, taken in conjunction with the observations above, suggests that PEM is characterised by a selective as well as an absolute decrease of IgA-containing cells in the jejunal mucosa. It is also supported by other studies which showed a decrease of IgA in the secretions of children with severe PEM. ${ }^{11-13}$ In those studies equivalent reductions in other proteins in the secretions were not observed, indicating the selective nature of the decrease.

A selective decrease of $\mathrm{S}$ IgA could occur in PEM as a result of increased catabolism of S IgA, faulty synthesis of S IgA components secondary to aminoacid deficiency, failure of terminal differentiation of IgA cells, immaturity of the $\mathbf{S} \operatorname{IgA}$ system, or as a result of maternal malnutrition during pregnancy. There is no evidence either to support or reject the possibility of increased breakdown of S IgA, but this is unlikely in view of the increased resistance of $\mathrm{S}$ IgA to proteolysis. ${ }^{18}$ Faulty synthesis of $\mathrm{S} \operatorname{IgA}$ is unlikely in view of the fact that secretory component appears to be present in normal amounts in the jejunal mucosa and IgA appears to be present in normal amounts in the serum. ${ }^{11-12}$ However, a failure in synthesis of the J-chain which links the IgA monomers to form the $\operatorname{IgA}$ dimer essential to secretion $^{19}$ cannot be excluded. Studies in animals and in isolated IgA deficiency in humans have shown that $\operatorname{IgA}$ (but not IgM or IgG) requires an intact T-cell system for the final differentiation of IgAbearing lymphocytes into actively secreting plasma cells. ${ }^{20-21}$ The clinical similarities between isolated IgA deficiency and PEM, ${ }^{12-24}$ the lymphopenia, ${ }^{2}$ and depressed cell-mediated immunity recorded in PEM, ${ }^{5-7}$ support the possibility of a failure in terminal differentiation of the IgA system. However, the normal values recorded for serum IgA in PEM ${ }^{11}$ do not. Several lines of evidence suggest the S IgA system in man is slow to develop, taking several years to reach full maturity. ${ }^{16}{ }^{25-26}$ The hiatus in IgA production during infancy appears to be bridged by an increased secretion of IgM. ${ }^{16}{ }^{25}$ The greatly reduced numbers of IgA-containing cells with relatively normal numbers of IgM-containing cells in PEM may indicate that the maturation process of the $\mathrm{S} \mathrm{IgA} \mathrm{system} \mathrm{is} \mathrm{retarded} \mathrm{in} \mathrm{this} \mathrm{condition.}$ The final possibility is that maternal malnutrition precedes the development of PEM in the infant. Chandra ${ }^{27}$ has shown that inbred rats fed a calorierestricted diet during pregnancy developed lymphopenia and a reduced antibody response to sheep red blood cells and that these abnormalities extended to the well nourished $F_{1}$ and $F_{2}$ generations. While there is no evidence either for or against this phenomenon in humans, research in this area could well be fruitful.

Whatever the cause of the S IgA deficiency in PEM it would appear that it can be largely corrected by a high protein/calorie diet. ${ }^{11}{ }^{13}$ However, despite a full clinical recovery, the S IgA levels in the infants studied by Sirisinha did not fully return to normal, raising the interesting possibility that the $\mathrm{S} \operatorname{IgA}$ deficiency preceeded the malnutrition. To what extent S IgA deficiency precedes or follows malnutrition can only be determined by prospective studies. The relationship between malnutrition and $\mathrm{S} \operatorname{IgA}$ deficiency is shown diagrammatically in the Figure. It is clear that once this cycle is established the affected infant is locked into a sequence of events that may lead to death, as bacterial overgrowth in the jejunum will lead to the additional feature of malabsorption in an already malnourished child. ${ }^{14}$ Fortunately this process can be reversed by an adequate diet; however in a world in which one-fifth of the population is seriously undernourished the identification of other, specific, risk factors-such as maternal malnutrition and poor hygiene, and elimination of waste-may be a more cost effective way of coping with the problem.

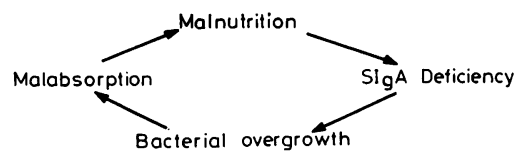

Figure Possible relationship between protein-energy malnutrition and $S \operatorname{Ig} A$ deficiency.

\section{References}

1 Phillips I, Wharton B. Acute bacterial infection in kwashiorkor and marasmus. Br Med J 1968; i: 407-9.

2 Chandra $\mathbf{R}$ K. Immunocompetence in undernutrition. J Pediatr 1972; 81 : 1194-200. 
3 Sirisinha S, Suskind R, Edelman R, Charupatana C, Olson R E. Complement and C3-proactivator levels in children with protein-calorie malnutrition and effect of dietary treatment. Lancet 1973; i: 1016-20.

4 Bhaskaram C, Reddy V. Cell mediated immunity in protein-calorie malnutrition. J Trop Pediatr 1974; 20: 284-6.

5 Moore D L, Heyworth B, Brown J. PHA-induced lymphocyte transformations in leucocyte cultures from malarious, malnourished, and control Gambian children. Clin Exp Immunol 1974; 17: 647-56.

${ }^{6}$ Heyworth B, Moore D L, Brown J. Depression of lymphocyte response to phytohaemagglutinin in the presence of plasma from children with acute proteinenergy malnutrition. Clin Exp Immunol 1975; 22: 72-7.

7 Moore D L, Heyworth B, Brown J. Effects of autologous plasma on lymphocyte transformation in malaria and in acute protein-energy malnutrition: comparison of purified lymphocyte and whole blood cultures. Immunology 1977; 33: 777-85.

8 Selvaraj R J, Seetharam Bhat K. Metabolic and bactericidal activities of leucocytes in protein-calorie malnutrition. Am J Clin Nutr 1972; 25: 166-74.

9 Keet M P, Thom H. Serum immunoglobulins in kwashiorkor. Arch Dis Child 1969; 44: 600-3.

10 McFarlane H, Reddy S, Adcock K J, Adeshina H, Cooke A R, Akene J. Immunity, transferrin, and survival in kwashiorkor. $\mathrm{Br}$ Med J 1970; iv: 268-70.

11 Reddy V, Raghuramulu N, Bhaskaram C. Secretory IgA in protein-calorie malnutrition. Arch Dis Child 1976; 51 : $871-4$.

12 Chandra $R$ K. Reduced secretory antibody response to live attenuated measles and poliovirus vaccines in malnourished children. $\mathrm{Br}$ Med J 1975; ii: 583-5.

13 Sirisinha S, Suskind R, Edelman R, Asvapaka C, Olson $\mathrm{R}$ E. Secretory and serum IgA in children with proteincalorie malnutrition. Adv Exp Med Biol 1974; 45: 389-98.

14 Heyworth B, Brown J. Jejunal microflora in malnourished Gambian children. Arch Dis Child 1975; 50: 27-33.

15 Green F H Y. An immunofluorescent study of the secretory antibody system in man. MD thesis, University of Manchester, 1978.
16 Savilahti E. Immunoglobulin-containing cells in the intestinal mucosa and immunoglobulins in the intestinal juice in children. Clin Exp Immunol 1972; 11: 415-25.

17 Søltoft J, Søeberg B. Immunoglobulin-containing cells in the small intestine during acute enteritis. Gut 1972; 13: 535-8.

18 Shuster J. Pepsin hydrolysis of IgA-delineation of two populations of molecules. Immunochemistry 1971; 8: 405-11.

19 Poger M E, Lamm M E. Localization of free and bound secretory component in human intestinal epithelial cells. $J$ Exp Med 1974; 139: 629-42.

20 Clough J D, Mims L H, Strober W. Deficient IgA antibody responses to arsanilic acid bovine serum albumin (BSA) in neonatally thymectomized rabbits. J Immunol 1971 ; 106: 1624-9.

21 Lawton A R, Wu L Y, Cooper M O. The cellular basis of IgA deficiency in humans. Adv Exp Med Biol 1974; 45: 373-80.

22 Ammann A J, Hong R. Selective IgA deficiency: presentation of 30 cases and a review of the literature. Medicine 1971 ; 50: 223-36.

23 Walker W A, Hong R. Immunology of the gastrointestinal tract. Part 2. J Pediatr 1973; 83: 711-20.

24 Chandra R K. Food antibodies in malnutrition. Arch Dis Child 1975; 50: 532-4.

25 Stiehm E R, Fudenberg H H. Serum levels of immune globulins in health and disease: a survey. Pediatrics 1966; 37: 715-27.

26 Haworth J C, Dilling C. Concentration of $\alpha$-A-globulin in serum, saliva, and nasopharyngeal secretions of infants and children. J Lab Clin Med 1966; 67: 922-33.

27 Chandra R K. Fetal malnutrition and postnatal immunocompetence. Am J Dis Child 1975; 129: 450-4.

Correspondence to Dr F Green, National Institute of Occupational Safety and Health - ALOSH, 944 Chestnut Ridge Road, Morgantown, West Virginia 26505, USA.

Received 17 April 1979 